\title{
Model Galat Spasial Untuk Jumlah Produksi Padi Tahun 2014 Di Jawa Barat
}

\author{
Spatial Error Models For Rice Plant Production on Year 2014 \\ In West Java
}

\author{
Alicia Anggelina Lumbantoruan ${ }^{1 *}$, Adi Setiawan ${ }^{2}$, Bambang Susanto ${ }^{3}$ \\ 1,2,3 Pendidikan Matematika, Universitas Kristen Satya Wacana Salatiga, \\ Jalan Diponegoro 52-60 Salatiiga, 50711 \\ ${ }^{1 *}$ Korespondensi Penulis. E-mail: lumbantoruanalicia@gmail.com, Telp: +6285213719195
}

\begin{abstract}
Abstrak
Indonesia merupakan salah satu negara produksi padi oleh karena itu luas lahan yang merupakan faktor utama yang sangat berpengaruh dalam produksi padi. Pad studi ini mengusulkan Model Galat Spasial dalam penerapan untuk jumlah produksi padi dan jumlah produksi padi tetangga. Model ini mengasumsikan bahwa kesalahan dalam model memiliki hubungan spasial antara satu daerah dan daerah lain. Data yang diolah adalah luas lahan produksi dan jumlah produksi padi di setiap kabupaten, di Jawa Barat pada tahun 2014. Matriks Pembobot juga digunakan, dalam menggambarkan kedekatan antar wilayah. Hasil yang diperoleh dari model spasial diketahui bahwa konstanta dan juga jumlah total produksi daerah tetangga tidak dipengaruhi berdasarkan hasil konstanta negatif dan juga hasil uji $\mathrm{t}$, yang menyatakan bahwa jumlah produksi tetangga daerah tidak mempengaruhi jumlah produksi padi. Regresi sederhana tanpa konstanta adalah model terbaik untuk produksi tanaman padi yang hanya didasarkan pada area produksi.
\end{abstract}

Keyword: Produksi Padi, Model Galat Spasial, Matriks Pembobot, Regresi Sederhana Tanpa Konstanta.

\begin{abstract}
Indonesia is one of the largest rice producing countries, therefore the land area is the main factor that influences rice plant production. This study proposes what so called the Spatial Error Model to be applied on the amount of rice and the neighbouring production. This model assumes that errors in the model have spatial relationships between one region and another. The processed data is the area of production land and the amount of rice production in each district, in West Java in year 2014. A contiguity matrix is also constructed, which describes the closeness between regions. The results obtained from the spatial error model is known that the constants and also that the amount of total production of neighbouring regions are not affect by the results of negative constants and also the results of the t test, which states that the total production of neighbouring regions does not affect the amount of rice production. Simple regression without constants is the best model for rice plant production that is only based on the area of production
\end{abstract}

Keyword: Rice Plant Production, Spatial Error Model, A Contiguity Matrix, Simple Regression Without Constants

\section{PENDAHULUAN}

Padi merupakan tanaman budidaya yang sangat bermanfaat bagi kehidupan dalam hal sebagai makan, karana ketika tanaman padi dipanen dilakukan pemisahan antara butir-butir padi yang disebut gabah dengan jerami padi. Selanjutnya gabah diolah menjadi beras yang mengandung 
kadar karbohidrat yang tinggi dan salah satu makan pokok di dunia, terutama di daerah Asia Tenggara, Asia Selatan, dan Asia Timur (Al Mutafa-II, 2017).

Indonesia merupakan salah satu negara yang berada di Asia Tenggara, mayoritas pekerjaan penduduk indonesia adalah petani yaitu sebesar 39,68 juta orang atau jika dalam bentuk persen yaitu sebesar 31,86\% dari jumlah penduduk yang bekerja yaitu 124,54 juta orang, menurut Kepala BPS Suhariyanto (Surya, 2017). Indonesia terdiri dari 34 provinsi dan Jawa Barat merupakan salah satu provinsi yang memproduksi padi terbanyak di Indonesia.

Salah satu contoh penelitian di sektor pertanian seperti penelitian model linear produksi padi, luas lahan dan curah hujan dengan prototype G2A, pengembangan ilmu optimasi yaitu ACO (Ant colony algorithm) dan model tak linear (Parhusip dan Somya, 2015).

Berdasarkan penelitian sebelumnya dapat diketahui luas panen mempengaruhi jumlah produksi, tetapi pada penelitian ini juga akan dibahas mengenai keterpengaruhan jumlah produksi padi wilayah tetangga terhadap jumlah produksi padi, menggunakan metode galat spasial. Model ini digunakan untuk menghitung pengaruh setiap variabel dan asumsikan bahwa galat dalam model memiliki korelasi spasial. Data yang diolah adalah luas lahan produksi dan jumlah produksi padi pada setiap kabupaten di Jawa Barat pada tahun 2014.

\section{METODE}

a. Analisis Data

Data yang digunakan yaitu data ganda karena berdasarkan dari banyaknya variabale independen yang digunakan yaitu luas lahan dan jumlah produksi padi tetangga. Dalam menentukan luas lahan dan jumlah produksi padi tetangga menggunakan data dari BPS dan untuk menetukan jumlah produksi padi tetangga perlu dilakukan penentuan wilayah yang bertetangga. Wilayah tetangga adalah daerah atau tempat yang berbatasan langsung dengan daerah yang diperhatikan. Konsep analisis data yang digunakan yaitu regresi galat spasial.

b. Model Regresi Ganda

Model regresi ganda yang digunakan dalam bentuk matriks karena berdasarkan bentuk data yang diolah.

Model tersebut:

$$
\begin{aligned}
& Y=X \beta+\varepsilon, \\
& \varepsilon \sim N\left(0, \sigma^{2} I\right),
\end{aligned}
$$

Dengan:

$Y$ : variabel respon berukuran $n \times 1$,

$X$ : matriks variabel independen berukuran $n \times(p+1)$,

$\varepsilon$ : vektor galat yang bebas otokorelasi berukuran $n \times 1$,

$\beta$ : vektor koefisien regresi berukuran $(p+1) \times 1$,

$n$ : banyaknya data yang diperoleh, dan

$p$ : banyaknya variabel independen.

Pendugaan nilai $\beta$ dan $\sigma^{2}$ adalah sebagai berikut (Setiawan,2017):

$$
\begin{aligned}
& \hat{\beta}=\left(X^{T} X\right)^{-1} X^{T} Y, \\
& \sigma^{2}=\frac{(Y-X \widehat{\beta})^{T}(Y-X \widehat{\beta})}{n-p-1} .
\end{aligned}
$$

Variabel respon merupakan data produksi padi di Provinsi Jawa Barat. Data produksi padi tidak dapat lepas dari wilayah dan juga pengaruh galat spasial, maka perlu menghitung menggunakan model galat spasial (spasial error model).

c. Model Galat Spasial

Model galat spasial merupakan salah satu bagian dari regresi spasial yang bentuknya linear dan memiliki faktor galat terhadap korelasi spasial. Bentuk umumnya sebagai berikut:

$$
Y=X \beta+u,
$$


dengan

$$
\begin{aligned}
& u=\lambda W u+\varepsilon, \\
& \varepsilon \sim N\left(0, \sigma^{2} I\right),
\end{aligned}
$$

$Y$ : variabel respon berukuran $n \times 1$,

$X$ : matriks variabel prediktor berukuran $n \times(p+1)$,

$\beta$ : vektor koefisien regresi berukuran $(p+1) \times 1$,

$\varepsilon$ : vektor galat yang bebas otokorelasi berukuran $n \times 1$,

$u$ : vektor galat yang diasumsi mengandung otokorelasi yang berukuran $n \times 1$,

$\lambda:$ parameter galat spasial, dan

$W$ : matriks berbobot pada wilayah berukuran $n \times n$ (Rahmawati, 2015).

Pendugaan nilai $\beta, \sigma^{2}$, dan $\lambda$ dapat dijelaskan berikut ini.

Karena $\varepsilon$ mempunyai distribusi normal maka bentuk persamaan fungsi dari $\varepsilon_{i}$ adalah

$$
f\left(\varepsilon_{i}\right)=\frac{1}{\sigma \sqrt{2 \pi}} \exp \left[-\frac{\varepsilon_{i}^{2}}{2 \sigma^{2}}\right] .
$$

dengan $i=1,2,3, \ldots, n$. Berdasarkan persamaan fungsi dari $\varepsilon_{i}$ maka didapatkan fungsi kepadatan peluang dari $f(\varepsilon)$ yaitu:

$$
\begin{aligned}
f(\varepsilon) & =f\left(\varepsilon_{1}\right) \cdot f\left(\varepsilon_{2}\right) \ldots f\left(\varepsilon_{n}\right), \\
& =\left[\left(\frac{1}{\sigma \sqrt{2 \pi}} \exp \left[-\frac{\varepsilon_{1}{ }^{2}}{2 \sigma^{2}}\right]\right) \ldots\left(\frac{1}{\sigma \sqrt{2 \pi}} \exp \left[-\frac{\varepsilon_{n}{ }^{2}}{2 \sigma^{2}}\right]\right)\right], \\
& =\frac{1}{(2 \pi)^{n / 2} \sigma^{n}} \exp \left[-\frac{\sum_{i}^{n} \varepsilon_{i}{ }^{2}}{2 \sigma^{2}}\right], \\
& =\frac{1}{(2 \pi)^{n / 2} \sigma^{n}} \exp \left[-\frac{\varepsilon^{T} \varepsilon}{2 \sigma^{2}}\right] .
\end{aligned}
$$

Dalam penentuan $\varepsilon$ dapat dilakukan dengan persamaan (6) untuk mendapatkan $u$, kemudian disubstitusikan ke persamaan (5) dengan hasil sebagai berikut:

$$
u=(I-\lambda W)^{-1} \varepsilon \text {, dan } \varepsilon=(Y-X \beta)(I-\lambda W) .
$$

Didapatkan fungsi kepadatan peluang dari variabel peubah respon $Y$ dengan $J$ adalah Jacobian, sebagai berikut:

$$
\begin{aligned}
f(Y)= & f(\varepsilon)|J|, \\
= & \frac{1}{(2 \pi)^{n / 2} \sigma^{n}} \exp \left[-\frac{\varepsilon^{T} \varepsilon}{2 \sigma^{2}}\right]\left|\frac{\partial \varepsilon}{\partial Y}\right|, \\
& L=\frac{1}{(2 \pi)^{\frac{n}{2}} \sigma^{n}} \exp \left[-\frac{\varepsilon^{T} \varepsilon}{2 \sigma^{2}}\right]|I-\lambda W| .
\end{aligned}
$$

Parameter $\beta$ dan $\sigma^{2}$ yang dicari akan memaksimumkan fungsi likelihood dan berarti juga memaksimumkan fungsi log likelihood yaitu:

$$
l=\ln |I-\lambda W|-\frac{n}{2} \ln \left(2 \pi \sigma^{2}\right)-\frac{\varepsilon^{T} \varepsilon}{2 \sigma^{2}} .
$$

Fungsi $\log$ likelihood di atas diturunkan terhadap $\beta$ dan kemudian disubstitusikan nilai $\varepsilon$ diperoleh

$$
\frac{\partial l}{\partial \beta}=-\frac{\partial\left(\varepsilon^{T} \varepsilon\right)}{\partial \beta}=-\frac{\partial\left[\left(Y^{T}-\beta^{T} X^{T}\right)(\mathrm{I}-\lambda W)^{T}(\mathrm{I}-\lambda W)(Y-X \beta)\right]}{\partial \beta},
$$

Pada persamaan di atas dilakukan lagi perumpamaan $M=(I-\lambda W)^{T}(I-\lambda W)$ dan $M$ simetris sehingga $M^{T}=M$, dengan begitu diperoleh bentuk berikut:

$$
\begin{aligned}
\frac{\partial l}{\partial \beta} & =-\frac{\partial\left[\left(Y^{T}-\beta^{T} X^{T}\right) M(Y-X \beta)\right]}{\partial \beta}, \\
& =-\left(-X^{T} M Y-X^{T} M Y+2 X^{T} M X \beta\right), \\
& =-2\left(X^{T} M X \beta-X^{T} M Y\right) .
\end{aligned}
$$

Pada tahap terakhir diperoleh $\hat{\beta}$ dengan $\frac{\partial \mathrm{l}}{\partial \beta}=0$ dan dilakukan substitusi nilai $M$ sebagai berikut: 


$$
\begin{gathered}
\hat{\beta}=\left(X^{T} M X\right)^{-1} X^{T} M Y, \\
\hat{\beta}=\left[X^{T}(I-\lambda W)^{T}(I-\lambda W) X\right]^{-1} X^{T}(I-\lambda W)^{T}(I-\lambda W) Y,
\end{gathered}
$$

Setelah mendapat $\hat{\beta}$ dilakukan turunan kedua untuk memenuhi syarat cukup dimana nilai $-\frac{\partial\left(\varepsilon^{T} \varepsilon\right)}{\partial \beta}$ diturunkan terhadap $\beta$ yang didapatkan nilai bahwa turunan kedua kurang dari 0 .

Pendugaan $\sigma^{2}$ dengan menggunakan persamaan log likelihood dengan cara melakukan penurunan terhadap $\sigma^{2}$ untuk memperoleh hasil $\hat{\sigma}^{2}$ :

$$
\frac{\partial l}{\partial \sigma^{2}}=\frac{\ln |I-\lambda W|-\frac{n}{2} \ln \left(2 \pi \sigma^{2}\right)-\frac{\varepsilon^{T} \varepsilon}{2 \sigma^{2}}}{\partial \sigma^{2}}=-\frac{n}{2 \sigma^{2}}+\frac{\varepsilon^{T} \varepsilon}{2\left(\sigma^{2}\right)^{2}},
$$

dengan $\frac{\partial l}{\partial \sigma^{2}}=0$, sehingga diperoleh:

$$
\hat{\sigma}^{2}=-\frac{(I-\lambda W)^{T}(Y-X \widehat{\beta})^{T}(I-\lambda W)(Y-X \widehat{\beta})}{n},
$$

Penentuan turunan kedua yang merupakan syarat cukup dengan melakukan permisalan $A$ kemudian diturunkan terhadap $\sigma^{2}$ dengan nilai $A$ adalah $\frac{\partial l}{\partial \sigma^{2}}$

$$
A=-\frac{n}{2 \sigma^{2}}+\frac{\varepsilon^{T} \varepsilon}{2\left(\sigma^{2}\right)^{2}}
$$

Hasil $A^{\prime}$, merupakan hasil turunan kedua terhadap $\boldsymbol{\sigma}^{2}$ sehingga hasilnya disubstitusikan $\boldsymbol{\sigma}^{2}$ dengan $\hat{\sigma}^{2}$ yang berarti bahwa $\hat{\sigma}^{2}$ adalah penyebab maksimum dari $\sigma^{2}$.

Pendugaan parameter untuk $\lambda$ tidak bisa dilakukan dengan penurunan kedua dari $\hat{\beta}$ karena adanya nilai $|I-\lambda W|$ maka digunakan $\lambda$ yaitu antara 1 sampai -1 (Amelia, 2012). Dalam penelitian ini digunakan nilai $\lambda$ yaitu sebesar 0.5 karena dengan menggunakan nilai $\lambda$ sebesar 0.5 , maka didapatkan hasil yang optimal untuk data yang diolah.

\section{d. Matriks Pembobot}

Matriks berbobot merupakan matriks yang menggambarkan kedekatan antara satu wilayah dengan wilayah yang lain, untuk wilayah yang bertetangga maka $w_{i j}=1$ sedangkan untuk wilayah yang tidak bertetangga maka $w_{i j}=0$ (Djuraida, 2012).

Dalam penentuan matriks pembobot Queen diformulasikan (Dalughu, 2018):

$$
W_{i j, \text { Queen }}=\frac{W_{i j}}{\sum_{j=1}^{n} W_{i j}} \text {. }
$$

e. Uji Kelayakan Model

Dalam melakukan pengujian kelayakan ada terbagi beberapa ujian yaitu koefisien determinasi merupakan metode seberapa jauh kecocokan dari suatu model regresi:

$$
R^{2}=\frac{J K R}{J K T}
$$

Jika hasil yang diperoleh 1 maka garis regresinya cocok secara sempurna sedangkan kalau 0 artinya tidak ada hubungan antara variabel prediktor dengan variabel respon.

Uji $F$ dengan langkah-langkah

1. Menentukan hipotesis:

$H_{0}$ : luas lahan dan jumlah produksi tetangga tidak mempengaruhi jumlah produksi,

$H_{l}$ : luas lahan dan jumlah produksi tetangga mempengaruhi hasil produksi.

2. Menghitung nilai $F_{\text {hitung }}$ :

$$
F_{\text {hitung }}=\frac{J K R / 2}{J K G /(n-3)} \text {. }
$$

3. Menghitung $F_{\text {tabel }}$ :

$$
F_{\text {tabel }}=q f((1-\alpha), p,(n-p-1)) \text {. }
$$

4. Penarikan kesimpulan.

Jika $F_{\text {hitung }} \geq F_{\text {tabel }}$ maka $H_{0}$ ditolak.

Uji $t$ dengan langkah-langkah:

1. Membuat hipotesis: 
- Pengaruh luas lahan terhadap jumlah produksi

$H_{0}$ : luas lahan mempengaruhi jumlah produksi,

$H_{l}$ : luas lahan tidak mempengaruhi jumlah produksi.

- Pengaruh jumlah produksi tetangga terhadap jumlah produksi

$H_{0}$ : jumlah produksi tetangga mempengaruhi jumlah produksi,

$H_{l}$ : jumlah produksi tetangga tidak mempengaruhi jumlah produksi.

2. Menghitung kovariansi

$$
\operatorname{Cov}(\beta)=\sigma^{2}\left(X^{\prime} X\right)^{-1},
$$

3. Menghitung nilai dari $t_{\text {hitung }}$

$t_{\text {hitung }}=\frac{\beta_{i}}{s\left(\beta_{i}\right)}$.

dengan

$\beta_{i}=$ koefisien regresi masing-masing variabel,

$s\left(\beta_{i}\right)=$ standarisasi error dari $\beta_{i}$ yaitu akar dari diagonal $\operatorname{Cov}(\beta)$.

4. Menghitung $t_{\text {tabel }}$ dengan $\alpha=5 \%$ yaitu:

$t_{\text {tabel }}=t\left(1-\frac{\alpha}{2},(n-p-1)\right)$.

5. Penarikan kesimpulan hipotesis

Jika $\left|t_{\text {hitung }}\right|>t_{\left(1-\frac{\alpha}{2}, n-p-1\right)}$, maka $H_{0}$ ditolak.

dalam melakukan uji kelayakan maka perlu melakukan perhitungan sebagai berikut:

a. Menghitung jumlah kuadrat total:

$J K T=\sum_{i=1}^{n}\left(Y_{i}-\bar{Y}\right)^{2}$,

b. Menghitung jumlah kuadrat galat:

$J K G=\sum_{i=1}^{n}\left(Y_{i}-\widehat{Y}_{l}\right)^{2}$,

dengan

$\widehat{Y}_{l}=X \hat{\beta}$.

c. Menghitung jumlah kuadrat regresi

$J K R=J K T-J K G$,

\section{Sumber data}

Data yang diolah merupakan data produksi padi di Provinsi Jawa Barat Tahun 2014 yang diperoleh dari Badan Pusat statistik (BPS). Data tersebut sebagai berikut:

Tabel 1. Luas Panen, dan Produksi Padi Jawa Barat 2014

\begin{tabular}{lcc}
\hline \multicolumn{1}{c}{ Kabupaten } & Luas lahan & Produksi \\
\hline Bogor & 86.492 & $517 . .442$ \\
Sukabumi & 155.042 & 897.485 \\
Cianjur & 151.890 & 830.545 \\
Bandung & 79.141 & 462.977 \\
Garut & 160.668 & 972.890 \\
Tasikmalaya & 131.069 & 881.026 \\
Ciamis & 73.605 & 448.641 \\
Kuningan & 59.365 & 356.550 \\
Cirebon & 85.346 & 520.017 \\
Majalengka & 105.558 & 634.260 \\
Sumedang & 77.867 & 475.190 \\
Indramayu & 225.983 & 1.361 .374 \\
Subang & 171.190 & 964.845 \\
Purwakarta & 38.060 & 198.964 \\
Karawang & 189.533 & 1.122 .582 \\
Bekasi & 85.616 & 439.054 \\
Bandung Barat & 42.999 & 256.687 \\
Pangandaran & 33.398 & 157.035 \\
\hline
\end{tabular}


Variabel- variabel penelitian

$X_{1}$ : Luas Panen Produksi Padi di Jawa Barat 2014.

$X_{2}$ : Jumlah Produksi Padi Tetangga di Jawa Barat 2014.

$Y$ : Produksi Padi di Jawa Barat 2014.

Pengambilan sampel

Data yang diolah pada penelitian ini adalah data produksi padi pada kabupaten- kabupaten di Jawa Barat, karena adanya pertimbangan dari perbedaan yang cukup besar pada produksi padi dan juga luas panen di daerah perkotaan dan kabupaten.

\section{HASIL DAN PEMBAHASAN}

\section{Pengolahan data:}

Langkah- langkah yang digunakan yaitu:

1. Menentukan peta Jawa Barat,

2. Membuat matriks pembobot queen dengan menentukan matriks bobot dan membuat matriks menggunakan formula,

3. Menghitung jumlah produksi tetangga,

4. Mendapatkan model galat spasial,

5.Melakukan pengujian kecocokan model dengan menentukan koefisien determinasi,uji $F$ dan uji t,

6.Merupakan alternatif jika model tidak cocok, maka dikeluarkan variabel yang tidak berpengaruh dan perhitungan menggunakan model regresi sederhana.

2. Hasil analisis awal:

Pada Tabel 1 terdapat data yang berasal dari Badan Pusat Statistik, dengan data tersebut dapat dilihat Gambar 1 yang menyatakan hubungan antara luas panen dan produksi padi yaitu naik artinya semakin besar luas panen maka semakin besar juga jumlah produksinya.

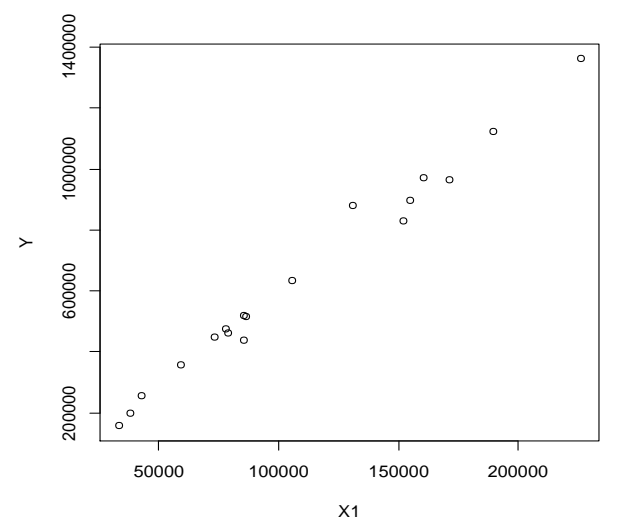

Gambar 1. Scatter plot hubungan Luas Panen produksi padi

\section{Peta}

Peta berfungsi yang akan membantu untuk penentuan matriks wilayah dan membantu dalam penentuan jumlah produksi tetangga. Perhatian penelitian ini hanya ke 18 kabupaten di Jawa Barat seperti dinyatakan pada Gambar 2. 


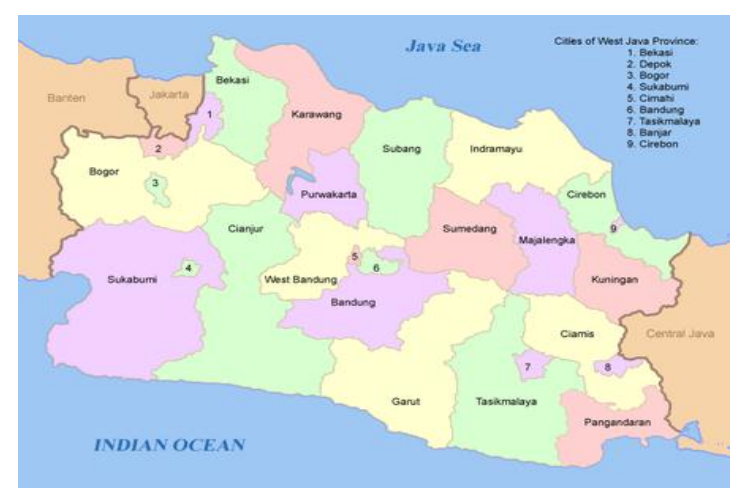

Gambar 2. Peta Provinsi Jawa Barat (wikepedia)

\section{Matriks Pembobot Queen}

\section{a. Bentuk Matriks}

Bedasarkan Gambar 2 didapatkan wilayah yang bertetangga dan yang tidak bertetangga, pada wilayah yang saling bertetangga memiliki bobot 1 sedangkan wilayah yang tidak bertetangga memiliki bobot 0 , kemudian setelah itu diterapkan ke bentuk matriks.

$$
W_{i j}=\left[\begin{array}{llllllllllllllllll}
0 & 1 & 1 & 0 & 0 & 0 & 0 & 0 & 0 & 0 & 0 & 0 & 0 & 0 & 1 & 1 & 0 & 0 \\
1 & 0 & 1 & 0 & 0 & 0 & 0 & 0 & 0 & 0 & 0 & 0 & 0 & 0 & 0 & 0 & 0 & 0 \\
1 & 1 & 0 & 1 & 1 & 0 & 0 & 0 & 0 & 0 & 0 & 0 & 0 & 1 & 1 & 0 & 1 & 0 \\
0 & 0 & 1 & 0 & 1 & 0 & 0 & 0 & 0 & 0 & 1 & 0 & 0 & 0 & 0 & 0 & 1 & 0 \\
0 & 0 & 1 & 1 & 0 & 1 & 0 & 0 & 0 & 0 & 1 & 0 & 0 & 0 & 0 & 0 & 0 & 0 \\
0 & 0 & 0 & 0 & 1 & 0 & 1 & 0 & 0 & 1 & 1 & 0 & 0 & 0 & 0 & 0 & 0 & 1 \\
0 & 0 & 0 & 0 & 0 & 1 & 0 & 1 & 0 & 1 & 0 & 0 & 0 & 0 & 0 & 0 & 0 & 1 \\
0 & 0 & 0 & 0 & 0 & 0 & 1 & 0 & 1 & 1 & 0 & 0 & 0 & 0 & 0 & 0 & 0 & 0 \\
0 & 0 & 0 & 0 & 0 & 0 & 0 & 1 & 0 & 1 & 0 & 1 & 0 & 0 & 0 & 0 & 0 & 0 \\
0 & 0 & 0 & 0 & 0 & 1 & 1 & 1 & 1 & 0 & 1 & 1 & 0 & 0 & 0 & 0 & 0 & 0 \\
0 & 0 & 0 & 1 & 1 & 1 & 0 & 0 & 0 & 1 & 0 & 1 & 1 & 0 & 0 & 0 & 1 & 0 \\
0 & 0 & 0 & 0 & 0 & 0 & 0 & 0 & 1 & 1 & 1 & 0 & 1 & 0 & 0 & 0 & 0 & 0 \\
0 & 0 & 0 & 0 & 0 & 0 & 0 & 0 & 0 & 0 & 1 & 1 & 0 & 1 & 1 & 0 & 1 & 0 \\
0 & 0 & 1 & 0 & 0 & 0 & 0 & 0 & 0 & 0 & 0 & 0 & 1 & 0 & 1 & 0 & 1 & 0 \\
1 & 0 & 1 & 0 & 0 & 0 & 0 & 0 & 0 & 0 & 0 & 0 & 1 & 1 & 0 & 1 & 0 & 0 \\
1 & 0 & 0 & 0 & 0 & 0 & 0 & 0 & 0 & 0 & 0 & 0 & 0 & 0 & 1 & 0 & 0 & 0 \\
0 & 0 & 1 & 1 & 0 & 0 & 0 & 0 & 0 & 0 & 1 & 0 & 1 & 1 & 0 & 0 & 0 & 0 \\
0 & 0 & 0 & 0 & 0 & 1 & 1 & 0 & 0 & 0 & 0 & 0 & 0 & 0 & 0 & 0 & 0 & 0
\end{array}\right]
$$

\section{b. Matriks Pembobot Queen}

Matriks yang didapatkan sebelumnya dilakukan perhitungan menggunakan formula queen, yang menghitung jumlahan tiap baris pada matriks bobot lalu membagi elemen -elemen tiap baris dengan jumlahannya. Matriks yang dihasilkan ini akan digunakan dalam perhitunggan di model galat spasial.

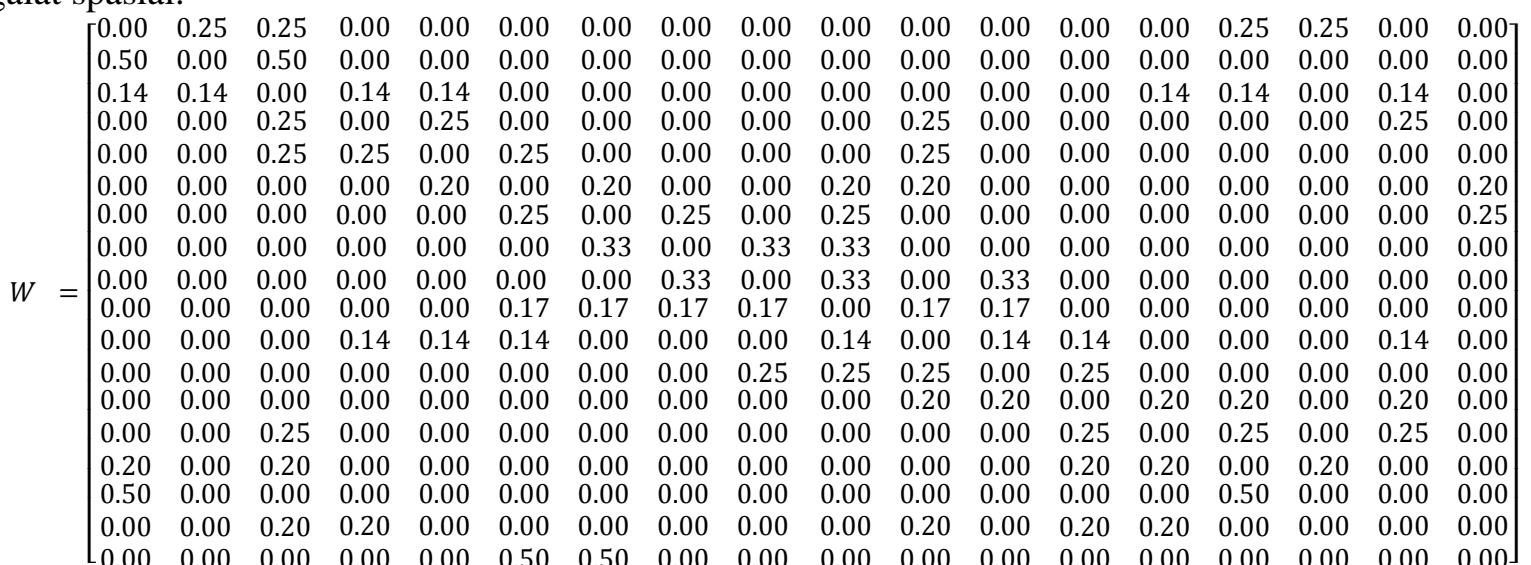
c. Jumlah produksi tetangga

Karena dalam penelitian ini menggunakan jumlah produksi tetangga, maka perlu melakukan penjumlahan produksi padi di setiap wilayah yang bertetangga yaitu sebagai berikut: 
Tabel 2. Jumlah produksi tetangga

\begin{tabular}{lc}
\hline Kabupaten & $\begin{array}{c}\text { Jumlah Produksi } \\
\text { Tetangga }\end{array}$ \\
\hline Bogor & 3289666 \\
Sukabumi & 1347987 \\
Cianjur & 4429027 \\
Bandung & 2535312 \\
Garut & 2217353 \\
Tasikmalaya & 3120401 \\
Ciamis & 1596486 \\
Kuningan & 2035303 \\
Cirebon & 2352184 \\
Majalengka & 4042798 \\
Sumedang & 5101674 \\
Indramayu & 2594312 \\
Subang & 3414797 \\
Purwakarta & 3174659 \\
Karawang & 2950850 \\
Bekasi & 1640024 \\
Bandung Barat & 2932521 \\
Pangandaran & 1329667 \\
\hline
\end{tabular}

Berdasarkan Tabel 2 dapat dilihat persebaran data dengan bantua aplikasi R yaitu pada Gambar 3 .

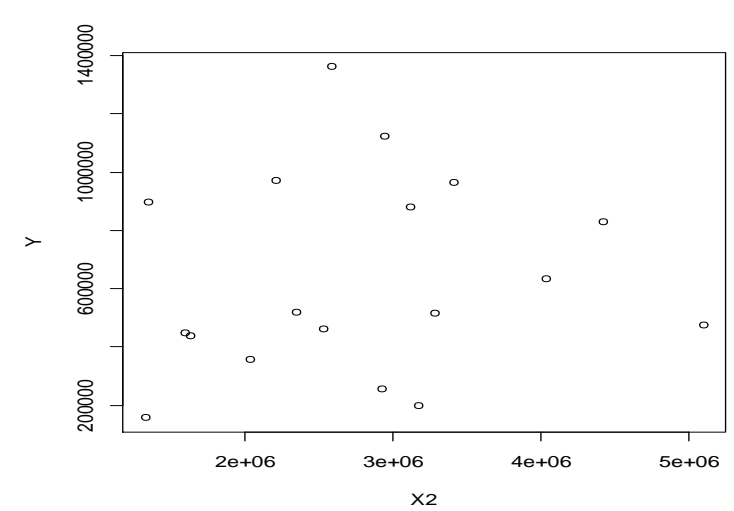

Gambar 3. Scatter plot hubungan dari jumlah produksi $(Y)$ dan jumlah produksi tetangga $\left(X_{2}\right)$.

\section{Model Galat Spasial}

Model galat spasial yang didapatkan yaitu:

$$
Y=-28519.9930+6.0736 X_{1}+0.0025 X_{2}+U .
$$

Dari persamaan produksi padi di atas dapat dilihat pengaruh dari kedua prediktor bernilai positif dan untuk koefisien bernilai negatif, maka dapat dikatakan ada pengaruh kedua perdiktor terhadap produksi tetangga.Setelah mendapatkan persamaan hasil produksi maka akan dilakukan uji kelayakan model.

Berdasarkan koefisien determinasi didapat hasil sebesar $98.61 \%$ artinya model menjelaskan 98.61\% dari data sedangkan sisanya tidak bisa dijelaskan dengan model. Pada uji $F$ diperoleh $F_{\text {hitung }} \geq F_{\text {tabel }}$ sebesar $534.4033 \geq 3.68232$ maka $H_{0}$ ditolak, artinya luas lahan dan jumlah produksi padi tetangga mempengaruhi jumlah produksi padi.

Sedangkan untuk uji $t$ berbeda karena hipotesis pertama yaitu $H_{0}$ ditolak, artinya luas lahan mempengaruhi hasil produksi dengan $\left|t_{\text {hitung }}\right|>t_{\left(1-\frac{\alpha}{2}, n-p-1\right)}$ atau 35.17129 $>2.13145$, tetapi pada pengujian hipotesis kedua didapatkan $H_{0}$ diterima karena $\left|t_{\text {hitung }}\right|<t_{\left(1-\frac{\alpha}{2}, n-p-1\right)}$ 
atau $0.2712582<2.13145$ yang artinya bahwa jumlah produksi tetangga tidak mempengaruhi hasil produksi. Dapat disimpulkan bahwa jumlah produksi padi hanya dipengaruhi luas lahan.

\section{Model Regresi Sederhana tanpa Konstanta}

Model yang diperoleh:

$$
Y=5.910027 X_{1}
$$

dengan artinya jika ditambakan luas lahan sebesar satu hektar akan menambah jumlah produksi padi sebanyak 5,910027 ton dan sebaliknya. Model regresi sederhana tanpa konstanta yang menjadi hasil dalam penelitian ini, diperoleh garis regresi yang ada pada Gambar 4 yang berguna untuk melihat persebaran data luas lahan dan jumlah produksi.

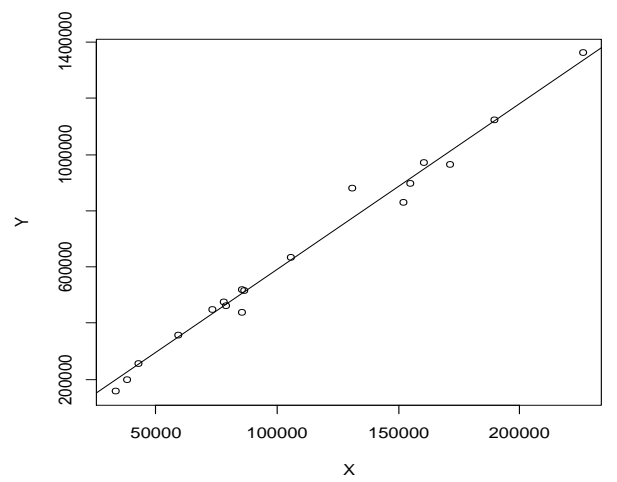

Gambar 4. Scatter plot hubungan dari jumlah produksi dan luas lahan serta garis regresinya

Pada model tersebut dilakukan uji kelayakan model dengan nilai koefisien determinasi yaitu $98.63 \%$, maka garis regrersi sederhana tanpa konstanta lebih baik dan uji t yaitu $t_{\text {hitung }}$ sebesar 74.49361 dan $t_{\text {tabel }}$ sebesar 2.119905 dapat diambil kesimpulan bahwa luas lahan mempengaruhi jumlah produksi padi.

\section{SIMPULAN}

Berdasarkan hasil yang diperoleh model terbaik untuk produksi padi di Jawa Barat adalah model regresi sederhana tanpa konstanta sehingga model yang didapatkan sebagai berikut:

$$
Y=5.910027 X_{1} \text {, }
$$

yang artinya jika jumlah produksi padi hanya dipengaruhi pada luas lahan dan tidak dipengaruhi oleh jumlah produksi tetangga. Hal ini berarti jika luas lahan ditambakan sebesar satu hektar akan menambah jumlah produksi padi sebanyak 5,910027 ton. Dengan kata lain, produksi padi rata-rata setiap hektarnya adalah 5,910027 ton. Oleh karena itu, model galat spasial tidak cocok digunakan pada kasus ini.

\section{DAFTAR PUSTAKA}

Amelia, M. (2012): Penerapan Regresi Spasial Untuk Data Kemiskinan Kabupaten Di Pulau Jawa. Skripsi. Fakultas Matematikan dan Ilmu Pengetahuan Alam. Institut Pertania Bogor. Bogor.

Anselin, L. (1999): Spasial Econometri. Dallas: School of Sosial Sciences.

Badan Pusat Statistik. (2015): Jawa Barat Dalam Angka 2015. Badan Pusat Statistik Jawa Barat. Bandung.

Dalughu, A. (2018): Model Autoregressif Spasial untuk Jumlah produksi Tanaman Pekerbunan di Kabupaten Halmahera Utara tahun 2012. Skripsi. Fakulta Ilmu Alam dan Teknologi Rekayasa. Universitas Halmahera. Tobelo.

Djuraida, A. (2012): Regresi Spasial untuk Menentukan Faktor-Faktor Kemiskinan di Provinsi Jawa Timur. Statistika. Vol. 12, No. 1. 1 - 8 Mei 2012. 
Mubtadiah, L. (2011): Estimasi Parameter Model Regresi Spasial Error Dengan Metode Maximum Likelihood. Skripsi, Fakultas Sains dan Teknologi. Universitas Islam Negeri (UIN) Maulana Malik Ibrahim. Malang.

Nuryadi, S. P., Astuti, T. D., Utami, E. S., \& Budiantara, M. (2017). Dasar-Dasar Statistik Penelitian.

Parhusip, H.A. dan Ramos, S. (2015): Prototype G2A (GSTAR dan GIS untuk Analisa data dan Optimasi data Pertanian dan Pendesaan). Tisara Grafika. Salatiga.

Rahmawati, R., Safitri, D., dan Fairuzdhiaya, O.M. (2015): Analisa Spasial Pengaruh Tingkat Pengaruh terhadap Kemiskinan Di Indonesia. Media Statistika. Vol. 8 No. 1, Juni 2015.

Riadi, E. (2016): Staistika Penelitian (Analisis Manual dan IBP SPSS), ANDI, Yogyakarta.

Rossche. (2011). Berkas:Map of West Java With Cities and Regencies Names.png. Wikipedia.URT:https://id.wikipedia.org/wiki/Berkas:Map_of_West_Java_with_cities_and_r egencies_names.png.

Setiawan, A. (2017): Analisis Data Statistik. Tisara Grafika. Salatiga.

Surya, ANTARA. 2017. Februari 2017, Sektor Pertanian Serap Banyak Tenaga Kerja. Tempo.co. 5 Mei 2017. URT:_https://bisnis.tempo.co/read/872715/februari-2017-sektorpertanian-serap-banyak-tenaga-kerja/full\&view=ok [tanggal akses] 